\title{
Rehabilitation in Mine Closure - Environmental, Economic \& Social Tradeoff in Opencast Coal Mine - A Case Study
}

\author{
Dr. Manoj Kumar, $\operatorname{Mgr}(\mathbf{M})^{*}$ \\ $C C L$, Coal India Limited \\ B Tech (M), M Tech (Env Sc \& Engg), MBA, LLB, PGDELP, APGDRE, PhD \\ *Corresponding Author: Dr. Manoj Kumar, Mgr(M), CCL, Coal India LimitedB Tech (M), M Tech
} (Env Sc \& Engg), MBA, LLB, PGDELP, APGDRE, PhD

\begin{abstract}
This paper presents an overview of requirements of rehabilitation, restoration, reclamation and remediation, the terms usually interchangeable and closely linked in the mining areas, its environmental, economic \& social tradeoff Indian coal mining scenarios. This study is based on two scenario, scenario I as being practiced as per MCP guidelines and Scenario II as introducing solar PV power plant in MCP process. The study reveals that scenario II has an edge over Scenario I in the field of environment, Social and economic tradeoff. Rehabilitation process in scenario II would restrict 0.18 Million tons of GHG emission @ 7114.4 tons of CO2e per annum, equivalent to $634 \mathrm{Ha}$ of forest absorbing CO2. Rehabilitation process will further benefits about thirty thousand population covering $9.33 \%$ of the household in the nearby community by providing clean energy at the tune of $6624.0537 \mathrm{MWh} / \mathrm{year}$. Economic benefit of this rehabilitation process may include 4.3 crores of revenue per year amounting to Rs. 30 crores to the mine management and Rs. 43 crores to the communities after the closure of mine activities. This would facilitate the mine management to fund the corpus for escrow fund from 12th year itself amounting to 30 crores. This rehabilitation process will result into increased reimbursement opportunity by Rs. 10 crores over 5.9 crores as in scenario I. This will facilitate the mine management in resolving their inability to reimburse the corpus fund deposited in escrow fund as per MCP guideline.
\end{abstract}

Keywords: Rehabilitation, GHG, MCP, solar PV, Escrow

\section{INTRODUCTION}

Mine closure plans are specific to each mine, and include details on how the mining company will close the mine site, how environmental protection will be achieved, and how the site will be returned to an acceptable state for a pre-arranged land use. The terms reclamation, remediation, rehabilitation, and restoration the $4 \mathrm{R}$, are all used to describe mine closure activities that attempt to alter the biological and physical state of a site. The terms are sometimes used interchangeably, and are closely linked, but refer to distinct steps in the preparation of the site for another use:

- Remediation: The cleanup of the contaminated area to safe levels by removing or isolating contaminants. At mine sites, remediation often consists of isolating contaminated material in preexisting tailings storage facilities, capping tailings and waste rock piles with clean topsoil, and collecting and treating any contaminated mine water if necessary.

- Reclamation: The physical stabilization of the terrain (dams, waste rock piles), landscaping, restoring topsoil, and the return of the land to a useful purpose.

- Restoration: The process of rebuilding the ecosystem that existed at the mine site (where applicable) before it was disturbed. The science of mine reclamation has evolved from simple revegetation activities to a discipline which involves using native plants to mimic natural ecosystem development over an extended period of time.

- Rehabilitation: The establishment of a stable and self-sustaining ecosystem, but not necessarily the one that existed before mining began. In many cases, complete restoration may be impossible, but successful remediation, reclamation, and rehabilitation can result in the timely establishment of a functional ecosystem. 


\subsection{Necessity of Rehabilitation}

For opening a new mine as Greenfield project or increasing the capacity of brownfield projects, mine owners have to obtain a social license (SL), which is an intangible, informal approval or acceptance of the community to have the mine in the community. In the past mining operations were abandoned without closure methods without mitigating physical and environmental impacts, have negatively influenced the ability of mining firms to obtain a social license. In Indian scenario mining firms have to obtain prior environmental clearance (EC) for all new projects or activities listed in the Schedule to this notification; Expansion and modernization of existing projects or activities listed in the Schedule to EIA notification 2006 with addition of capacity beyond the limits specified for the concerned sector, that is, projects or activities which cross the threshold limits given in the Schedule, after expansion or modernization; any change in product - mix in an existing manufacturing unit included in Schedule beyond the specified range. This is as per Environment Impact Assessment (EIA) notification 1994, EIA notification 2006 amended there on. This system of obtaining prior approval of EC have the provision of public hearing $(\mathrm{PH})$ synonymous to $\mathrm{SL}$ as per stage 3 of clause 7(i) of said notification, vide which mining firm has to take the consent of stakeholders, who also considers the historic activity of the mining firms before giving their consent. These historic activity are nothing but are the activities addressed towards closure of mines by the past mine managers before abandonment of mines. Mine managers have to share its plan for closure in EIA study and how the closure will ensure that the community will not be harmed by the mine operations, closure, or post-closure conditions. All aspects of the environment, such as soil, water, air, are considered during closure planning. Mine owners shall be required to obtain mine closure certificate from coal controller to effect that the protective reclamation and rehabilitation work in accordance with approved mine closure plan (MCP) / final MCP have been carried out. Rehabilitation being the major issues.

\subsection{World Scenario}

As per Garcia D H (2008), legal frameworks for managing mine reclamation in South America are established in Argentina, Bolivia, Colombia, Ecuador, Brazil, Chile, and Peru etc. Closure guidelines exist for Canada, Mexico, and the United States in North America. Closure aspects for mining facilities in Europe are closely linked with the conditions of planning permission for the mine. Closure guideline for South-eastern and Eastern Europe, Central Asia and Caucasus as part of its mission to advance and protect peace and the environment (United Nations et al, 2005) and are linked to ongoing and new mining efforts.

\subsection{Indian Scenario}

Developing countries like India were having few or no mine closure requirements before Garcia 2008. In the absence of well-defined closure regulations, companies used to choose closure guidance from international sources such as the World Bank and the International Finance Corporation for few of its mines. Before 2008, it was in 2003 Govt of India vide Notification GSR 229 (E) \& 230 ( E) made amendments in Mineral Concession Rules, 1960 and Mineral Conservation and Development Rules, 1988 respectively. As per these amendments, all the existing mining lessees are required to submit the "Progressive Mine Closure Plan" along with prescribed financial sureties within 180 days from date of notification. Further, the mining lessee is required to submit "Final Mine Closure Plan" one year prior to the proposed closure of the mine. In the notification, it has been enunciated that the "Progressive Closure Plan" and "Final Closure Plan" should be in the format and as per the guidelines issued by the Indian Bureau of Mines.

In 2003, under the aegis of Ministry of Environment \& Forest (MoEF) a meeting was held for Rehabilitation of Abandoned Mine Voids and Old OB Dumps. As per recommendation of meeting held on 31.03.03 at MOEF, GoI, New Delhi, under Chairmanship of IG, Forest, coal companies to prepare a comprehensive scheme for rehabilitation of abandoned mine voids and old OB dumps for next five years. Ministry of Coal (MoC), GoI was to set up a committee to look into the rehabilitation of old Mines \& afforestation work. Broad objective of the scheme were

- Take measures to facilitate restoration of disturbed eco-system which in context, was to restore the disturbed water regime near mine area and raising vegetation on degraded land.

- Reclamation of degraded land including external OB dumps, back filled areas and subsided area. This was to include physical and biological reclamation. Physical reclamation to include only 
minor grading, leveling of land that are must for facilitating 'active biological reclamation'. Stability of external OB dumps \& to check erosion were to be included.

- Hydro-reclamation of abandoned mine- This were to include taking measures that will facilitate storage of water in the mine void to minimize the degradation of quality of water stored in the mine void and take measures to protect the quality of surface water and also recharge the ground water.

- Control the fire in coal seam/reject dumps.

- Take measures to ensure safety within the mine lease area.

- To improve landscape and aesthetics within the lease area.

It was only on 27.08.2009 when Ministry of Coal, GoI formulated guidelines for mine closure for coal and lignite. MoC asks coalmine owners to incorporate MCP in their project report/ mine plan / feasibility report and to obtain approval from the competent authority. Mining company has to open Escrow Account to a scheduled bank prior to obtaining permission for opening a mine from Coal Controller. The MCP to include amount of money @ Rs. 6 lakhs/ha for opencast mine \& @ Rs. 1 lakhs/ha for underground mines. The proportionate amount to be deposited in escrow account on early basis. The MCP to include two component, one progressive/concurrent MCP and other as final MCP. There is provision of $20 \%$ reimbursement after $4^{\text {th }} \mathrm{yr}$ upon satisfaction of coal controller.

\subsection{Objective}

\section{Comparing two scenario of MCP}

1. Scenario I : Restoration of land after implementation of MCP(3R's)

2. Scenario II : Inclusion of Rehabilitation of land after implementation of MCP by inclusion of Solar PV power plant in MCP process (4R's)

\subsubsection{Scenario- I}

As per MCP guideline 2013, MCP process to include Dismantling of Structures (Fig 1(a)), Permanent Fencing of mine void - quarry/Pit top etc. and other dangerous area(Fig 1(b)), Sealing of mine entries(Fig 1(c)), Subsidence Management \& post closure subsidence monitoring for UG if any(Fig 1(d)), Grading of high wall slopes(Fig 1(e)), Reclamation of abandoned quarry including backfilling, leveling, biological reclamation(Fig 1(f)), OB dump reclamation including handling/dozing, technical and or biological reclamation, landscaping, plantation(Fig 1(g)), monitoring/testing of parameters for three years (Fig 1(h)), entrepreneurship development including vocational/skill development training for sustainable income of affected people(Fig 1(i)), miscellaneous and other mitigative measures, manpower cost for supervision, third party audit of progressive mine closure by CMPDI, ICFRE, FRI etc. (Fig 1(j)). These activities to include Remediation, Reclamation and Restoration.

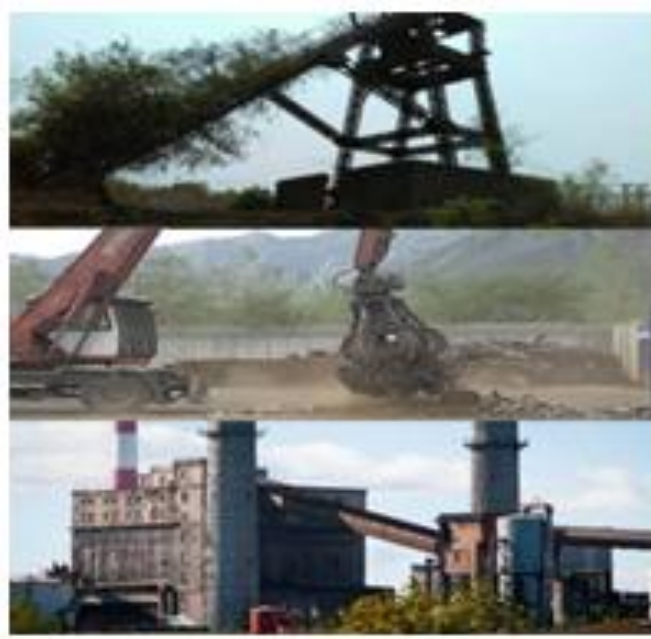

Fig1 (a). Dismantling of Structures

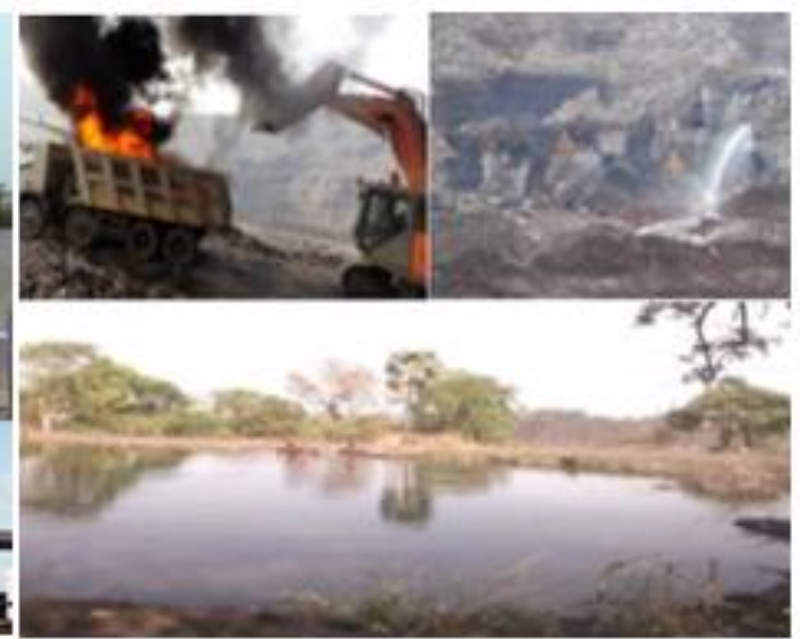

Fig1 (b). Permanent Fencing of mine void -

quarry/Pit top etc. and other dangerous area 


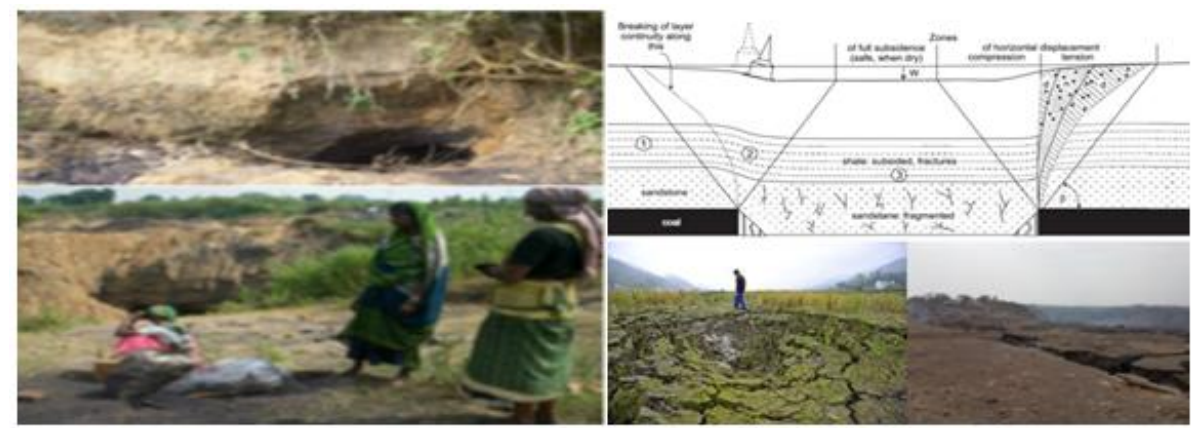

Fig1 (c). Sealing of mine entries

Fig1 (d). Subsidence Management \& post

closure subsidence monitoring

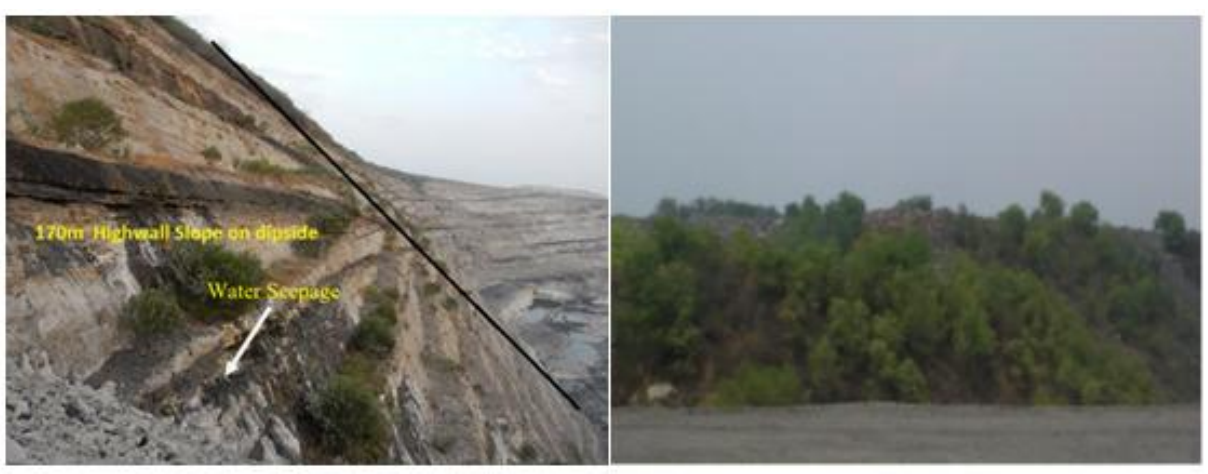

Fig1 (e). Grading of highwall slopes $\quad$ Fig1 (f). Reclamation of abandoned quarry including backfilling, leveling, biological reclamation

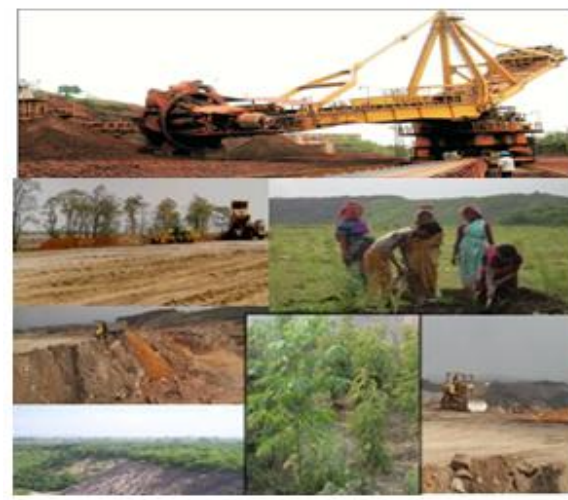

Fig1(g). OB dump reclamation including handling/dozing

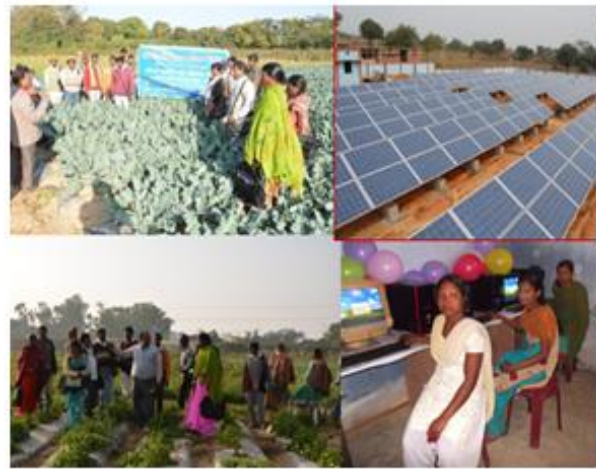

Fig1 (i). Development of entrepreneurship (Vocational/ skill development training for sustainable income of affected people)

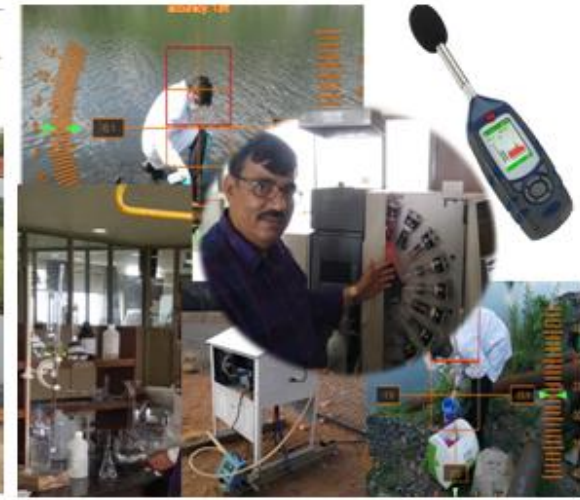

Fig1 (h). Monitoring/ Testing of parameters

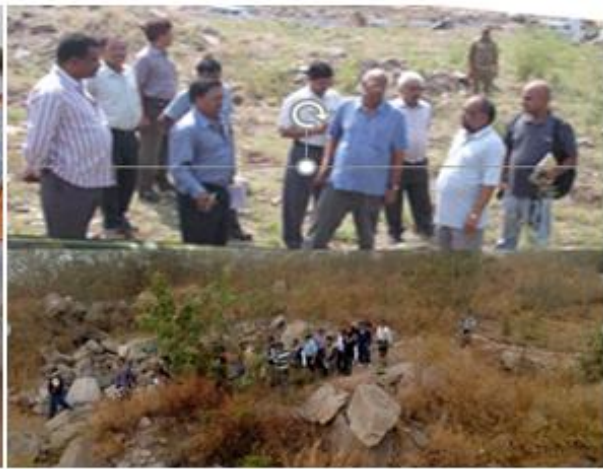

Fig1 (j). Third party audit 


\subsubsection{Scenario II}

Rehabilitation in mine closure process after induct of solar photovoltaic system on non-forest land along with provisions made in guideline 2013. This activity to be included in the head 'entrepreneurship development scheme' as developed in scenario I. This new activities enrich the 4R'S approach of the mine closure after mining is complete i.e. Remediation, Reclamation, Restoration and Rehabilitation. This activity will ensure a complete new and improved land use.

Though this approach is not been practiced. This is a conceptual approach and may be included in MCP with slight modification. Under provisions of para 7 of guideline for MCP (2013) the concept of inducting photovoltaic system over the external overburden dump on the non-forest land with a plea of conservation of environment. This concept will not only earn revenue for the project but also in reimbursing the amount invested in installation of solar power plant and its maintenance as per para 6 of MCP guideline 2013. This approach of rehabilitation may help stakeholders in a better and sustainable manner.

This concept include using the non-forest area where generally the external OB dumps are initially planned during the start of mine. The overburden are to be dumped and terraced properly by making benches and $28^{\circ}$ or more slope as per the provisions as laid down in Coal Mines Regulation 1957 and amended thereon and statutory conditions imposed by statutory bodies like MoEFCC, Pollution board, Directorate General of Mines safety etc. while granting permission.

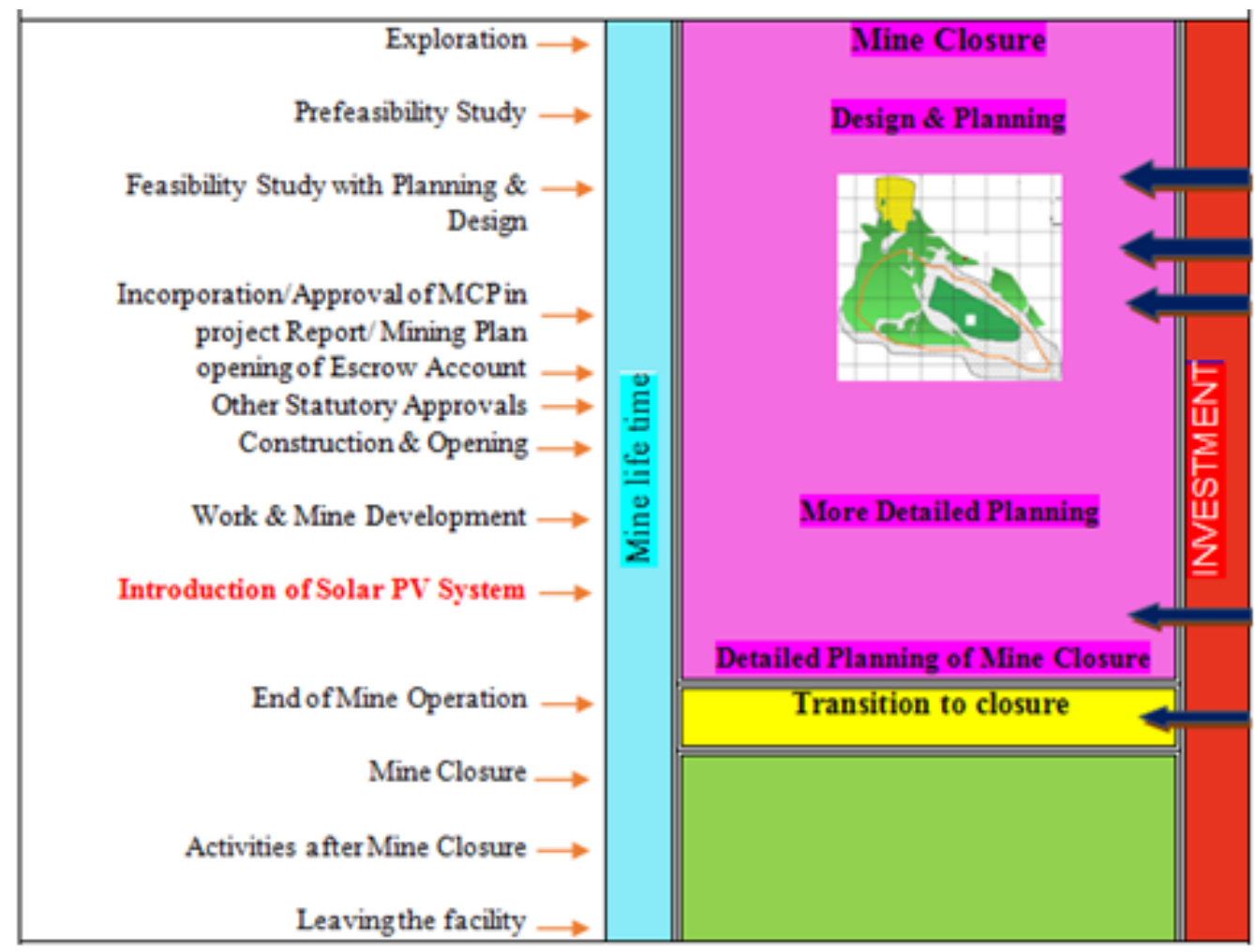

Fig2. Mine Closure Activity

Source: Mineral intelligence capacity analysis pp 3/12

\subsection{A Case Study}

An alternative scenario was tried to develop by incorporating installation of solar photovoltaic power plant on non-forest land without attracting the provisions of section 2(ii)/2(iii) for diversion/rediversion / change in land use provisions of forestland for non-forestry purpose (Fig. 2). For this study a promising, mine with the rated capacity of more than 10 MTY coal located at East Bokaro coalfield of Bokaro District of Jharkhnad was selected as a model. 1x10 MW solar photovoltaic power plant is proposed to be installed over external overburden dump proposed at north-western part of the study area. This power plant is in addition to the activity proposed in scenario II and excluding bio-reclamation over about $20 \mathrm{Ha}$ (Table 1). The difference in land use for Scenario I \& Scenario II has been shown at fig. 3 . 
Rehabilitation in Mine Closure - Environmental, Economic \& Social Tradeoff in Opencast Coal Mine - A Case Study

Table1. Post Mining Land use of Study Area

\begin{tabular}{|c|c|c|}
\hline Land use (Area in $\mathrm{Ha}$ ) & Scenerio I & Scenerio II \\
\hline Plantation on backfilled area & 160.54 & 160.54 \\
\hline Void Filled with Water & 135.21 & 135.21 \\
\hline Plantation on External Dump & 95.24 & 75.24 \\
\hline Solar PV Plant & 0.00 & 20.00 \\
\hline Public Use & 45.08 & 45.08 \\
\hline Road in public use & 4.40 & 4.40 \\
\hline Green belt & 27.5 & 27.5 \\
\hline Undisturbed Land & 53.35 & 53.35 \\
\hline Residential Colony & 5.00 & 5.00 \\
\hline Company use & 26.52 & 26.52 \\
\hline Total & 552.84 & 552.84 \\
\hline
\end{tabular}

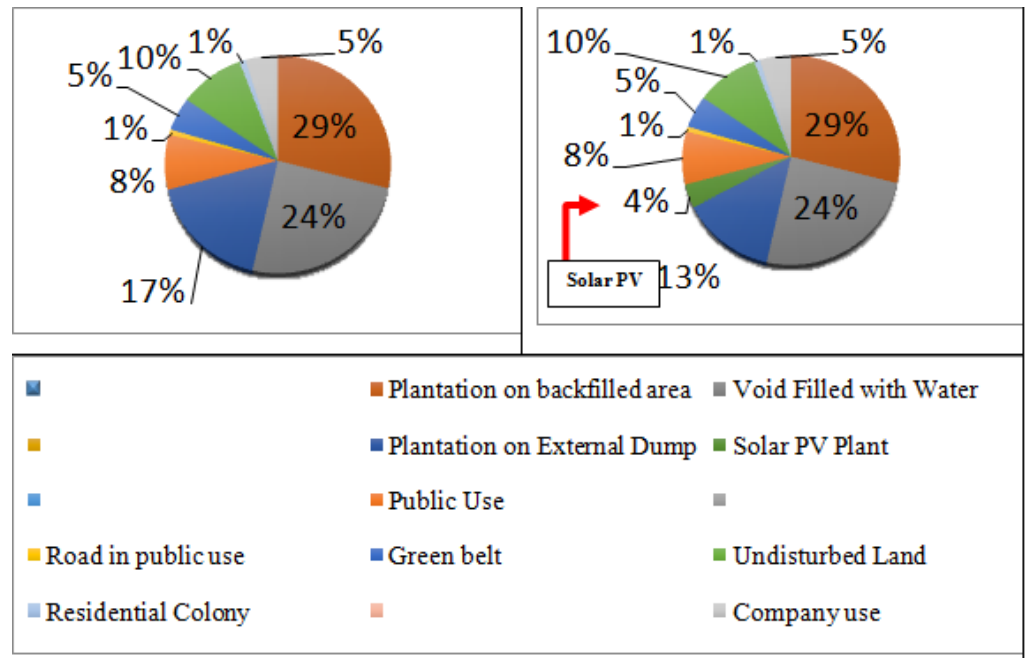

Fig3. Land use of Scenerio I \& Scenerio II

(left : Post mining LU - Scenerio I \& Right : Post mining LU - Scenerio II)

\subsection{Assessment of Economic Tradeoff}

The study area is an opencast coalmine. As per provisions of guidelines of MCP 2013, an escrow fund provisioning to be made for a minimum amount of Rs. 3317 Lakhs @ of Rs. 6 lakhs/ha and assuming no rise in wholesale price index. Considering life of mine to be 20 years, an annual corpus of 166 lakh and in total 5505 to be deposited up to the end of life of mine (Fig. 4).

Economic benefit from attaining the solar PV project its payback period i.e. after $8^{\text {th }}$ year up to end of life is about 30 crores @ 4.3 crores/yr from $14^{\text {th }}$ year to $20^{\text {th }}$ year (Table 2).

Table2. Economic benefit for scenario II

\begin{tabular}{|r|r|r|r|r|r|r|r|r|}
\hline Year & $14^{\text {th }}$ & $15^{\text {th }}$ & $16^{\text {th }}$ & $17^{\text {th }}$ & $18^{\text {th }}$ & $19^{\text {th }}$ & $20^{\text {th }}$ & Total \\
\hline Amount in Rs. Lakhs & 430 & 430 & 430 & 430 & 430 & 430 & 430 & 3010 \\
\hline
\end{tabular}

Scenario II will result into increased reimbursement opportunity before 25 th year, the year up to which claim for reimbursement is to be made, is in the tune of Rs. 10 crores over 5.9 crores in scenario I (Table 3 and Fig. 5).

Table3. Reimbursement opportunity

\begin{tabular}{|c|c|c|c|c|c|c|c|c|c|}
\hline year & $8^{\text {th }} y r$ & $9^{\text {th }} \mathrm{yr}$ & $10^{\text {th }} \mathrm{yr}$ & $11^{\text {th }} \mathrm{yr}$ & $12^{\text {th }} \mathrm{yr}$ & $13^{\text {th }} \mathrm{yr}$ & $14^{\text {th }} \mathrm{yr}$ & $15^{\text {th }} \mathrm{yr}$ & $16^{\text {th }} \mathrm{yr}$ \\
\hline Reimbursement Scenario-I & 30 & 30 & 30 & 30 & 32 & 34 & 34 & 33 & 33 \\
\hline Reimbursement Scenario-II & 178 & 335 & 557 & 32 & 32 & 34 & 34 & 35 & 35 \\
\hline Difference & 148 & 305 & 547 & 2 & 0 & 0 & 0 & 2 & 2 \\
\hline year & $17^{\text {th }} \mathrm{yr}$ & $18^{\text {th }} \mathrm{yr}$ & $19^{\text {th }} \mathrm{yr}$ & $20^{\text {th }} \mathrm{yr}$ & 21 st yr & $22^{\text {nd }} \mathrm{yr}$ & $23^{\mathrm{rd}} \mathrm{yr}$ & $24^{\text {th }} \mathrm{yr}$ & $25^{\text {th }} \mathrm{yr}$ \\
\hline Reimbursement Scenario-I & 31 & 31 & 29 & 27 & 25 & 26 & 26 & 27 & 31 \\
\hline Reimbursement Scenario-II & 33 & 33 & 31 & 29 & 27 & 28 & 28 & 29 & 33 \\
\hline Difference & 2 & 2 & 2 & 2 & 2 & 2 & 2 & 2 & 2 \\
\hline
\end{tabular}


Rehabilitation in Mine Closure - Environmental, Economic \& Social Tradeoff in Opencast Coal Mine - A Case Study

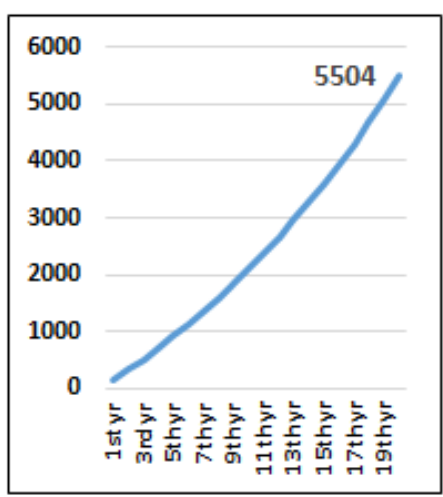

Fig4. Corpous for MCP

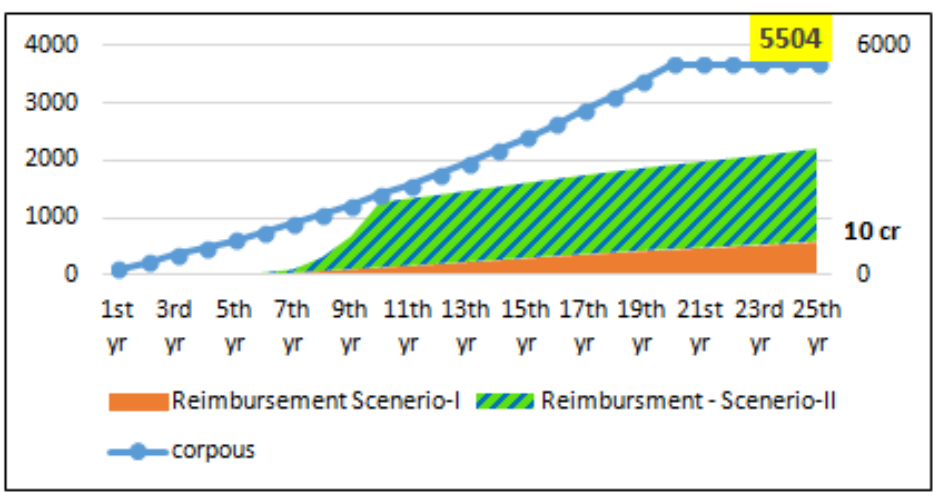

Fig5. Reimbursment Opportunity

\subsection{Assessment of Environmental Tradeoff}

Rehabilitation process in proposed scenario II of the mine closure process after end of mining process in $20^{\text {th }}$ year will result into 7114.4 tons of CO2e per annum ie 71144 tons of CO2e for the remaining life of the PV system (Fig. 6). This GHG reduction is equivalent to $634 \mathrm{Ha}(=654.3-20)$ ha or 1567.5 Acre (1616.9-49.5) of plantation would have been made absorbed the GHG.

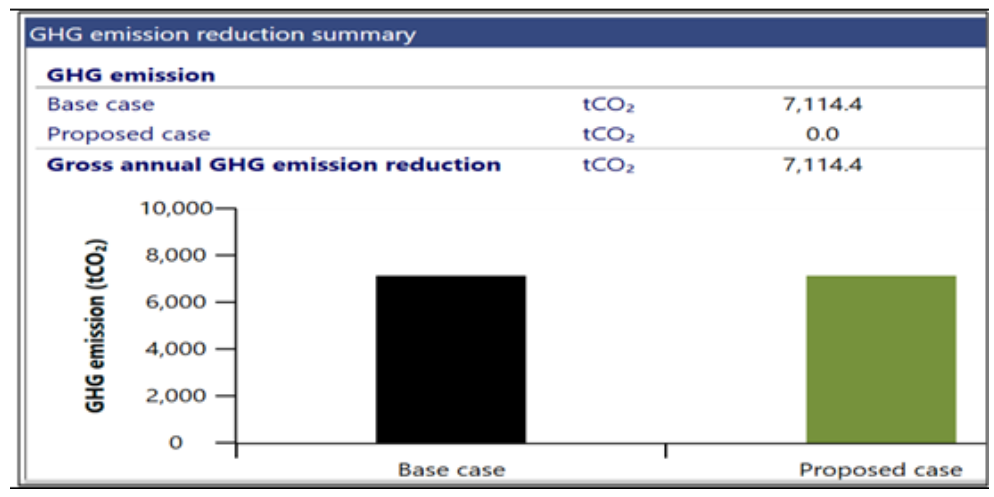

Fig.6 Annual GHG emission Reduction

\subsection{Assessment of Social Tradeoff}

From the assessment towards societal benefit of the mine closure practice after incorporating solar pv system in the module of MCP process it was found that the society leaving in an around the study area will be benefitted by Rs. 4.3 crores /year after the end of activity of mine i.e. after $20^{\text {th }}$ year in the name of profit earned by the project (Table 4). This is as because the PV power plant, which was installed by the mine management, will be in control of the society and has 10 more years of its life.

Table4. Benefits from solar PV Plant

\begin{tabular}{|r|r|l|l|l|l|l|l|l|l|l|r|}
\hline year & $21^{\text {st }}$ & $22^{\text {nd }}$ & $23^{\text {rd }}$ & $24^{\text {th }}$ & $25^{\text {th }}$ & $26^{\text {th }}$ & $27^{\text {th }}$ & $28^{\text {th }}$ & $29^{\text {th }}$ & $30^{\text {th }}$ & total \\
\hline Amount in Rs. Lakhs & 430 & 430 & 430 & 430 & 430 & 430 & 430 & 430 & 430 & 430 & 4300 \\
\hline
\end{tabular}

Considering the norms for an average household consumption/month as 90 unit, a total of 6049 house hold will be getting clean electricity from the already installed by the mine management of the study area (Table 5).

Table5. Expected Societal benefits to the nearby population

\begin{tabular}{|c|l|c|c|}
\hline SI No & \multicolumn{1}{|c|}{ Description } & Quantity & Unit \\
\hline 1 & Avg Household Consumption/Month & 90.00 & $\mathrm{kWh}$ \\
\hline 2 & Avg Household Consumption/Day & 3.00 & $\mathrm{kWh}$ \\
\hline 3 & Electricity exported to grid/yr & 6624.0537 & $\mathrm{MWh}$ \\
\hline 4 & Electricity Generation/day & 18148 & $\mathrm{kWh}$ \\
\hline 5 & Total Household & $64,835.00$ & Nos \\
\hline 6 & Total Household accommodated & 6049 & \\
\hline 7 & \% Of accommodation & $9.33 \%$ & \\
\hline 8 & No of Population benefitted & 30246 & \\
\hline
\end{tabular}




\section{CONCLUSION}

Post-closure may be a much longer period at many mines compared to the life of mine. Indeed, the consent of stakeholder, compliances of the prevailing statutory conditions and costs of closure should be a factor in the mine owner's decision to continue with a project.

The closure planning can be a good process to bring affected local communities back to the table. Even when a community disagrees with a new operation, or disagrees whether to close a current operation, it can provide constructive input on closure

On comparing scenario I \& scenario II it may be observed that scenario II is much better option. Scenario II has an edge over Scenario I in the field of environment, Social and economic tradeoff. Rehabilitation of the coalmines after mining is complete, if follows, scenario II would restrict 0.18 Million tons of CO2e @ 7114.4 tons of CO2e per annum which is equivalent to $634 \mathrm{Ha}$ of forest absorbing CO2. Rehabilitation process will further benefits about thirty thousand population covering $9.33 \%$ of the household in the nearby community by providing clean energy at the tune of 6624.0537 $\mathrm{MWh} /$ year. Economic benefit of this rehabilitation process may include 4.3 crores of revenue per year amounting to Rs. 30 crores to the mine management and Rs. 43 crores to the communities after the closure of mine activities. This would facilitate the mine management to fund the corpus for escrow fund from 12th year itself amounting to 30 crores. This rehabilitation process will result into increased reimbursement opportunity by Rs. 10 crores over 5.9 crores as in scenario I. This will facilitate the mine management in resolving the problem being faced in reimbursement of fund since targets to be achieved in progressive mine closure is not explicitly provided.

\section{ACKNOWLEDGEMENT}

The authors would like to acknowledge the coal mines officials of coal mining companies for extending their help and coordination to complete this study. We would also like to thank all for extending online and offline support for arriving to the objective of this study. The views presented by authors are solely their interpretation. We would also extend our regards to the publishers for making the things publish in right way.

\section{REFERENCES}

[1] Central Electricity Regulatory Commission, New Delhi (2016); "Determination of Benchmark Capital Cost Norm for Solar PV power projects and Solar Thermal power projects applicable during FY 2016-17"; Petition No. 17/SM/2015; Date of Order: 23rd March 2016; pp. 1-31.

[2] Compendium Of Gazette Notifications, Office Memoranda Under Environment Impact Assessment Notification, 2006, MoEF\&CC, Nov-2014, pp. 389-398.

[3] DEFRA. 2013, "Government GHG Conversion Factors for Company Reporting: Methodology Paper for Emission Factors" (July 2013); Department for Environment, Food and Rural Affairs, London, pp 27-40 (www.gov.uk/defra).

[4] Factsheet Mine closure process (overview of different phases and actions), Mineral intelligence capacity analysis pp 1-12. (http://data.geus.dk/MICASheetsEditor/document/25a37283-051e-423a-bf7dc2dcb0596d44.)

[5] Garcia D H (2008); "Overview Of International Mine Closure Guidelines" 3rd International Professional Geology Conference, Flagstaff, Arizona, USA, September 20-24, 2008.

[6] Jharkhand State Electricity Regulatory Commission (2018); "Order on Annual Performance Review for FY 2016-17 and Determination of Revised ARR and Tariff for the FY 2017-18 \& FY 2018-19 for Jharkhand Bijli Vitran Nigam Limited (JBVNL)"; Ranchi 27.04.2018, pp. 24 of 210.

[7] IPCC, 1997. Revised 1996 IPCC Guidelines for National Greenhouse Gas Inventories: Reference Manual (3). Chapter 4: Agriculture. Intergovernmental Panel on Climate Change. Paris, France.

[8] IPCC, 2006. IPCC Guidelines for National Greenhouse Gas Inventories: Volume 4: Agriculture, Forestry and other Land Use. Intergovernmental Panel on Climate Change. Paris, France. (http://www.ipccnggip.iges.or.jp)

[9] IPCC, 2015, Climate Change 2014, Synthesis Report; pp. 1-167 (ISBN 978-92-9169-143-2); (http://www.ipcc.ch.)

[10] Kumar Manoj (2015); "Public hearing in EIA Process - A platform for raising Environmental issues"; Vasundhara- The Earth, Special Volume 1, IJNEAS, ISSN : 2349-3763; October 2015, pp. 46-59. 
[11] Kumar M, Sangeeta (2015); 'Carbon Footprint Assessment Model for Opencast Coal Mine [2015]; IMEJ, Bhubaneshwar, Oct, 2015.

[12] Kumar Manoj (2016); "Issues in Public Hearing Process: Resolving \& Redressal Mechanism at Jharkhand"; Journal of Environmental and Social Sciences, Volume 3, Issue 1 - 2016, Open Science Publications, pp 01-09.

[13] Kumar Manoj (2016); "Public hearing in EIA Process - Exploring regional variation"; International Journal of Environment and Natural Sciences; vol. 9; pp. 9-21.

[14] Kumar Manoj (2017); "Where We Are and Where We Can Go through Public hearing Process in special reference to mining sector in Jharkhand"; Mine Tech, volume 38 No. 1, January-March 2017, pp. 22-32.

[15] MoC circular No.55011-01-2009-CPAM dated 07.01.2013 on "Guidelines for preparation of mine closure plan-Reg"; pp 1-13.

[16] MoC circular No. 55011-01-2009-CPAM dtd. 27.08.09 on "Guidelines for preparation of mine closure plan-Reg"; pp 1-12.

[17] Prno J. (2013). An analysis of factors leading to the establishment of a social license to operate in the mining industry. Resources Policy, Volume 38, Issue 4, p. 577-590.

[18] Sellers R \& Vogel P (2015); “Guidelines for Preparing Mine Closure Plans, May 2015”; DMP \& EPA; Government of Western Australia; pp. 1-100.

[19] United Nations Environment Programme, United Nations Development Programme, Organization for Security and Co-operation in Europe, and North Atlantic Treaty Organization (2005). Mining for Closure, Policies and Guidelines for Sustainable Mining Practice and Closure of Mines. pp. 97 (ISBN: 82-7701037-0)

[20] https://coal.nic.in/content/guidelines-preparation-mine-closure-plan-3.

[21] https://jbvnl.co.in/

[22] https://mercomindia.com/discom-developers-agree-renegotiated-tariff-\%E2\%82\%B94-95kwh-jharkhanddevelop-685-mw-solar-projects/

[23] http://cprindia.org/news/6519

Citation: Dr. Manoj Kumar, "Rehabilitation in Mine Closure - Environmental, Economic \& Social Tradeoff in Opencast Coal Mine - A Case Study", International Journal of Research in Environmental Science (IJRES), vol. 5, no. 3, pp. 16-24, 2019. Available: DOI: http://dx.doi.org/10.20431/2454-9444.0503003

Copyright: (C) 2019 Authors. This is an open-access article distributed under the terms of the Creative Commons Attribution License, which permits unrestricted use, distribution, and reproduction in any medium, provided the original author and source are credited. 